\title{
Genetic diversity in tetraploid switchgrass revealed by AFLP marker polymorphisms
}

\author{
J. Todd ${ }^{1}$, Y.Q. Wu ${ }^{1}$, Z. Wang ${ }^{1,2}$ and T. Samuels ${ }^{1}$ \\ Beijing, China \\ Corresponding author: Y.Q. Wu \\ E-mail: yanqi.wu@okstate.edu \\ Genet. Mol. Res. 10 (4): 2976-2986 (2011) \\ Received February 15, 2011 \\ Accepted June 28, 2011 \\ Published November 29, 2011 \\ DOI http://dx.doi.org/10.4238/2011.November.29.8
}

${ }^{1}$ Department of Plant and Soil Sciences, Oklahoma State University, OK, USA ${ }^{2}$ Institute of Animal Science, Chinese Academy of Agricultural Science,

\begin{abstract}
Switchgrass (Panicum virgatum) is a perennial warmseason grass native to North America that has been identified as a dedicated cellulosic biofuel crop. We quantified genetic diversity in tetraploid switchgrass germplasm collected at Oklahoma State University and characterized genetic relatedness among the collections from distinct regions. Fifty-six tetraploid accessions, including seven upland and 49 lowland genotypes from throughout the US, were examined. The amplified fragment length polymorphism (AFLP) procedure was utilized to generate DNA profiling patterns that were scored visually. Sixteen selective AFLP primer combinations were used to amplify 452 polymorphic bands. The accessions' genetic similarity coefficients, UPGMA (unweighted pairgroup method with arithmetic averaging) cluster analysis and principle coordinate analysis, were performed. The upland and lowland accessions clustered according to ecotypes, with one exception (TN104). Genetic similarity coefficients among the accessions ranged from 0.73 to 0.95 . Analysis of molecular variance (AMOVA) was performed, showing significant differences between the upland and lowland genotypes. The trnL marker confirmed that TN104 was a lowland genotype, but the $t r n \mathrm{~L}$ marker identification of upland and lowland genotypes was not consistent with the AFLP analysis in two germplasms (Miami and AR4).
\end{abstract}

Key words: Switchgrass; Panicum; AFLP; Germplasm; trnL(UAA); Biofuel 


\section{INTRODUCTION}

Switchgrass (Panicum virgatum) is a C4 perennial grass that is native to the United States east of the Rocky Mountains (Hitchcock, 1935; Waller and Lewis, 1979). It has become popular as a biofuel crop because of its perennial growth habit, high yielding potential on marginal lands, wide adaptation, excellent conservation attributes, and compatibility with conventional farming practices (McLaughlin et al., 1999). In addition switchgrass is beneficial to wildlife for shelter and reduces plowing, thus reducing soil erosion caused by exposing open soil to wind and water (Vogel, 2004). High yielding cultivars, which can be created by traditional breeding protocols, are required to satisfy the energy demand. Diverse germplasms (gene sources) are beneficial for crop improvement. Genetic diversity and relationships are better evaluated using DNA markers than morphological traits because DNA markers are unaffected by environmental factors (Singh et al., 1999). Amplified fragment length polymorphism (AFLP) is an important DNA fingerprinting technique that can be used to determine genetic distance and diversity (Meudt and Clarke, 2006). AFLP is a dominant marker system that uses PCR to amplify fragments of DNA (Meudt and Clarke, 2006). AFLP markers can be used in applications such as phylogenetics, population genetics, linkage mapping, and for many other purposes (Meudt and Clarke, 2006). Major advantages of the AFLP marker system over other molecular markers include multiple polymorphic markers generated in a single PCR and its high reliability.

Past molecular marker studies on genetic diversity analysis in switchgrass include random amplified polymorphic DNA (RAPD; Gunter et al., 1996; Casler et al., 2007), restriction fragment length polymorphism (RFLP; Missaoui et al., 2006), and simple sequence repeats (SSRs; Narasimhamoorthy et al., 2008; Cortese et al., 2010). Gunter et al. (1996) used RAPDs to assess the genetic diversity among and within 14 populations of switchgrass and to find markers that are useful for population identification. Casler et al. (2007) performed RAPDs on 46 remnant populations and 11 cultivars to discover if there was population differentiation and to evaluate possible correlations between genotypes, ecotypes, and geographic forms. They found little differentiation correlated with geography, but a small amount was associated with hardiness zones and ecotypes. Casler et al. (2007) also reported that plants from the same region could be highly unrelated to each other. They further indicated that their markers could not distinguish between cultivars and remnant wild populations. Missaoui et al. (2006) used RFLPs to assess the genetic variation between 21 switchgrass genotypes that were randomly selected from three synthetic cultivars ('Alamo', 'Kanlow' and 'Summer'); they found that there was higher diversity between upland and lowland accessions compared to genotypes within each of the cultivars. Missaoui et al. (2006) also found polymorphism for the trnL (UAA) chloroplastic marker associated with upland and lowland ecotypes. The trnL UAA intron region is in the chloroplasts of all plants (Pirie et al., 2007). It is part of the chloroplast DNA and is transferred through the maternal parent (Martinez-Reyna et al., 2001). Missaoui et al. (2006) found that this marker has a 49-nucleotide segment of DNA deletion in the lowland germplasm when aligned with upland germplasm. Narasimhamoorthy et al. (2008) studied the diversity of the USDA Germplasm Resources Information Network (GRIN) germplasm bank, and found that there was higher variation within populations than among populations. Cortese et al. (2010) combined marker and morphological data among 12 populations of switchgrass and could distinguish between upland populations based on geography. Their results also indicated that morphological and adaptive 
traits could be identified by molecular markers. Zalapa et al. (2010) used 55 SSR markers and six chloroplast markers to study diversity within and between 18 switchgrass cultivars ( 7 lowlands and 11 uplands). The SSR markers could discriminate ecotype correctly, but chloroplast markers alone (like the $t r n \mathrm{~L}$ marker) could not always distinguish ecotype (Zalapa et al., 2010).

Switchgrass breeding and genetic research has been performed at OSU since 1992 (McLaughlin and Kszos, 2005). A large switchgrass germplasm collection has been assembled as a result of this research. Our objectives were to characterize genetic diversity in the tetraploid switchgrass germplasm assembled at OSU from around the US, to analyze the genetic relatedness among the switchgrass germplasms and to try to distinguish upland from lowland germplasms using the $\operatorname{trn} \mathrm{L}$ marker.

\section{MATERIAL AND METHODS}

\section{Plant material DNA extraction}

Fifty-six tetraploid switchgrass plants maintained in an OSU switchgrass germplasm nursery were used in this study (Table 1) (Hopkins et al., 1996). Of these germplasms, 7 were classified as upland and 49 as lowland by previous morphological marker phenotyping (Taliaferro CM, unpublished results). DNA extraction was performed using the Zymo ZR Plant/Seed $\mathrm{Kit}^{\mathrm{TM}}$ (Zymo Research Corporation, CA, USA) according to manufacturer instructions. DNA quality of each sample was checked by $1 \%$ agarose gel electrophoresis. The concentration was measured using a Nanodrop ${ }^{\mathrm{TM}} 1000$ spectrophotometer (Nanodrop Products, DE, USA).

Table 1. Oklahoma State University switchgrass tetraploid germplasm collection used in the AFLP analysis.

\begin{tabular}{|c|c|c|c|c|c|}
\hline ID & Ecotype & Origin/reference & ID & Ecotype & Origin/reference \\
\hline Miami & Lowland & Miami, Florida & SWG043 & Lowland & Bristow, Oklahoma \\
\hline MS4 & Lowland & Yalobusha County, Mississippi & SWG044 & Lowland & Bristow, Oklahoma \\
\hline MS6 & Lowland & Mississippi & SWG045 & Lowland & Bristow, Oklahoma \\
\hline PANGBURN & Lowland & Arkansas & SWG046 & Lowland & Bristow, Oklahoma \\
\hline PI 422016 & Lowland & Florida & SWG047 & Lowland & Bristow, Oklahoma \\
\hline PMT 279 & Lowland & From Matt Sanderson & SWG048 & Lowland & Bristow, Oklahoma \\
\hline STUART & Lowland & Stuart, Florida & SWG049 & Lowland & Bristow, Oklahoma \\
\hline SWG002 & Lowland & A Pangburn selection & SWG051 & Lowland & Shawnee, Oklahoma \\
\hline SWG003 & Lowland & Union County, Arkansas & TX1 & Lowland & Texas \\
\hline SWG004 & Lowland & Yalobusha County, Mississippi & WABASSO & Lowland & Wabasso, Florida \\
\hline SWG005 & Lowland & Coffeyville, Mississippi & AR4 & Upland & Arkansas \\
\hline SWG020 & Lowland & Labled as Pathfinder from NB AES & MO100 & Upland & Butler Hollow Glades, Missouri \\
\hline SWG021 & Lowland & Stillwater, Oklahoma & MO101 & Upland & Hercules Glades, Missouri \\
\hline SWG022 & Lowland & Stillwater, Oklahoma & $\mathrm{NC1}$ & Upland & Fort Bragg, North Carolina \\
\hline SWG024 & Lowland & Bristow, Oklahoma & Summer & Upland & Nebraska \\
\hline SWG029 & Lowland & McAlester, Oklahoma & TN103 & Upland & Shelby County, Tennesse \\
\hline SWG030 & Lowland & McAlester, Oklahoma & TN104 & Upland & Tennessee \\
\hline SWG031 & Lowland & McAlester, Oklahoma & PI 315723 & Lowland & North Carolina \\
\hline SWG032 & Lowland & Bristow, Oklahoma & PI 315727 & Lowland & North Carolina \\
\hline SWG033 & Lowland & Bristow, Oklahoma & PI 315728 & Lowland & Maryland \\
\hline SWG034 & Lowland & Slick, Oklahoma & PI 414065 & Lowland & Arkansas \\
\hline SWG035 & Lowland & Slick, Oklahoma & PI 414070 & Lowland & Kansas \\
\hline SWG036 & Lowland & Bristow, Oklahoma & PI 421999 & Lowland & Arkansas \\
\hline SWG037 & Lowland & Bristow, Oklahoma & PI 476291 & Lowland & Maryland \\
\hline SWG038 & Lowland & Drumright, Oklahoma & PI 476293 & Lowland & New Jersey \\
\hline SWG039 & Lowland & Drumright, Oklahoma & PI 607837 & Lowland & Texas \\
\hline SWG040 & Lowland & Bristow, Oklahoma & PI 607838 & Lowland & Texas \\
\hline SWG042 & Lowland & Drumright, Oklahoma & PI 636468 & Lowland & Texas \\
\hline
\end{tabular}




\section{AFLP analysis}

The AFLP procedure was performed according to Vos et al. (1995), with modifications made according to $\mathrm{Wu}$ et al. (2005). The DNA was digested using EcoRI and MseI enzymes, and AFLP adapters were ligated to these DNA fragments. Fragments were pre-amplified by PCR using primer combinations based on the AFLP adaptors. Sixteen AFLP fluorescently labeled selective amplification primer combinations were used to characterize genetic diversity (Table 2). The quantity of primer combinations was selected because it was necessary to generate $>400$ polymorphic bands (loci), which were considered to be appropriate to estimate the diversity of a crop-like switchgrass. All PCRs were conducted using an Applied Biosystems 2720 thermocycler (Applied Biosystems Inc., IL, USA). Banding patterns were visualized on a $0.25-\mathrm{mM}$ thick $6.5 \%$ polyacrylamide gel with a 64 -tooth comb in a Li-COR 4300 DNA Analyzer (Li-Cor Inc., NE, USA) and run at $1500 \mathrm{~V}$ with scan speed 2 for $2.5 \mathrm{~h}$. A DNA size marker $(50-700 \mathrm{bp})$ was also loaded to determine the size of the fragments.

Table 2. Selective AFLP primer combinations used to amplify PCR bands in 56 switchgrass accessions.

\begin{tabular}{lccc}
\hline Primer combinations & TNB & NPB & PPB (\%) \\
\hline M-CAC/E-ACC & 36 & 25 & 69.4 \\
M-CAC/E-ACT & 36 & 25 & 69.4 \\
M-CTG/E-ACA & 55 & 32 & 58.2 \\
M-CTG/E-ACT & 39 & 29 & 74.4 \\
M-CTG/E-ACC & 42 & 27 & 64.3 \\
M-CTG/E-AGC & 41 & 25 & 61.0 \\
M-CTA/E-AAG & 52 & 34 & 65.4 \\
M-CTA/E-AGC & 43 & 29 & 67.4 \\
M-CTC/E-AAC & 47 & 33 & 70.2 \\
M-CTC/E-ACG & 41 & 29 & 70.7 \\
M-CAT/E-ACC & 44 & 37 & 84.1 \\
M-CAT/E-ACG & 43 & 28 & 65.1 \\
M-CAA/E-AAG & 46 & 31 & 67.4 \\
M-CAA/E-AGG & 39 & 29 & 74.4 \\
M-CAG/E-ACA & 27 & 21 & 77.8 \\
M-CAG/E-ACG & 27 & 452 & 66.7 \\
Total & 658 & 28.2 & - \\
Mean & 41.1 & 68.7
\end{tabular}

$\mathrm{TNB}=$ total number of bands; $\mathrm{NPB}=$ No. of polymorphic bands; PPB = percentage polymorphic bands.

\section{Data collection and analysis}

Polymorphic bands in each AFLP gel were scored visually as ' 1 ' for presence and ' 0 ' for absence for each of the 56 switchgrass accessions, while ' 9 ' was assigned to an ambiguous band. The bands were counted between $\sim 75$ and $204 \mathrm{bp}$. The collected data were analyzed using the NTSYSpc version $2.02 \mathrm{i}$ program for calculating simple-matching similarity coefficients, performing a cluster analysis, and a principle coordinate analysis (Rohlf, 1993). AMOVA was performed using GenAlex 6 (Peakall and Smouse, 2006), which partitioned the data between upland and lowland including and excluding TN104. Genetic diversity of switchgrass was calculated by Shannon's information index (Brown and Weir, 1983) and expected heterozygosity $\left(H_{\mathrm{E}}\right)$ (Lynch and Milligan, 1994) and unbiased $H_{\mathrm{E}}\left(U H_{\mathrm{E}}\right)$ (Hartl and Clark, 1997) using Genalex (Peakall and Smouse, 2006). 


\section{$\operatorname{Trn} \mathrm{L}$ analysis}

To clarify upland and lowland identities of the germplasm, especially TN104, the DNA used in the AFLP procedure of all the germplasms was processed with primers ' $c$ ' and 'd' as described by Taberlet et al. (1991) to amplify the trnL UAA intron region. 'Summer' and PI 421999 were used as controls because they were sequenced and confirmed as upland and lowland, respectively, by Missaoui et al. (2006). The purified DNA was sequenced at the OSU Recombinant DNA/Protein Resource Facility in both directions using primers from the PCRs and aligned using ClustalW in the MEGA software (ver. 4.0) (Kumar et al., 2008) program to determine the presence or absence of 49 nucleotides that are deleted in lowland switchgrass (Missaoui et al., 2006).

\section{RESULTS AND DISCUSSION}

\section{AFLP}

The 16 AFLP selective primer combinations generated a total of 658 markers. There were 452 polymorphic bands, resulting in a polymorphism percentage of $68.7 \%$. The similarity coefficients ranged from 0.73 (between pairs PI315727 and SWG005, PI76293 and SWG005, MO100 and SWG039) to 0.95 (between SWG031 and SWG024), with an average of 0.83. According to the UPGMA cluster tree (Figure 1), two major Clusters (I and II) had a similarity of $78 \%$. All the lowland germplasms were in Cluster I, and all upland germplasms were in Cluster II, with the exception of TN104, which was previously classified as upland according to morphology. Cluster I was divided into two subclusters, A and B, with a similarity of $79.6 \%$. Subcluster A had the most genotypes and could be divided into sections $i$ and ii at $81.2 \%$ similarity. In the principle coordinate map (Figure 2), most of the lowland genotypes were clustered tightly together to the left; but the rest, including all the upland types, were scattered across the field towards the right. The principal coordinate analysis was mostly consistent with the cluster analysis (Figure 1). The clustering separation of upland and lowland plants supported the conclusion that lowland-tetraploid and upland-tetraploid switchgrasses represent different heterotic groups (Martinez-Reyna and Vogel, 2008).

There was cluster division among germplasm according to region, but there were some exceptions. Cluster IB contained germplasm from the east coast of the United States and TN104 from TN. Cluster IAi contained germplasm from Florida and Mississippi, while cluster IAii contained mostly germplasms from the central United States, but also a few from Mississippi and Florida. These differences were most likely caused by adaptation to geographic regions. Other studies (Casler et al., 2007; Narasimhamoorthy et al., 2008; Zalapa et al., 2010) found that most of the germplasm subclustered according to adaptive regions. The upland group of II and the lowland groups of IAi and IAii and IB were all possible sources of variation for breeding. To ensure adequate diversity, plants from each of the groups could be selected as germplasm when developing cultivars. Crosses between members of these groups could be made to test for heterosis in field-based studies. These groups could be kept separate and improved and then crossed for heterosis in synthetics, hybrids or semi-hybrids (Brummer, 1999).

The upland and lowland germplasm mostly clustered separately, which is consistent with the results of Narasimhamoorthy et al. (2008) and Zalapa et al. (2010), but TN104, an 


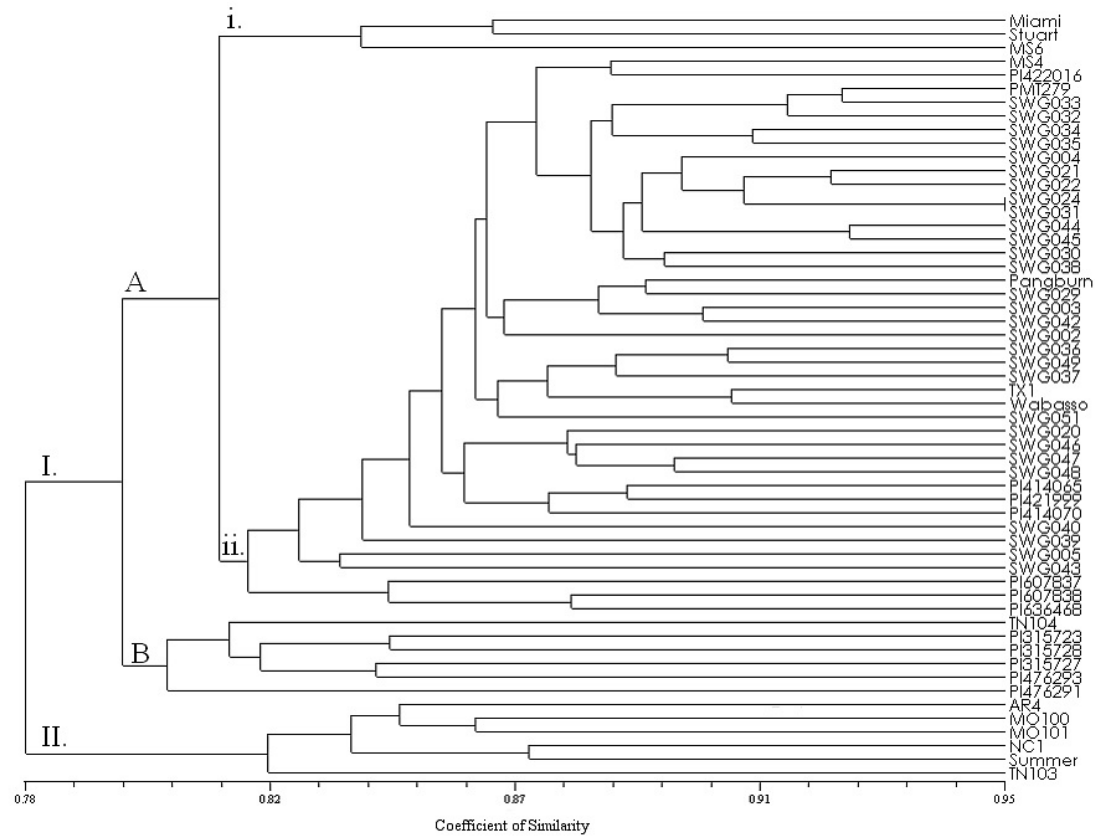

Figure 1. UPGMA phenogram of genetic diversity based on simple-match similarity coefficients derived from switchgrass AFLP markers. Roman numerals I and II represent the major groupings. A and B are subdivisions of I and the lower case Roman numerals $\mathrm{i}$ and ii are subdivisions of A.

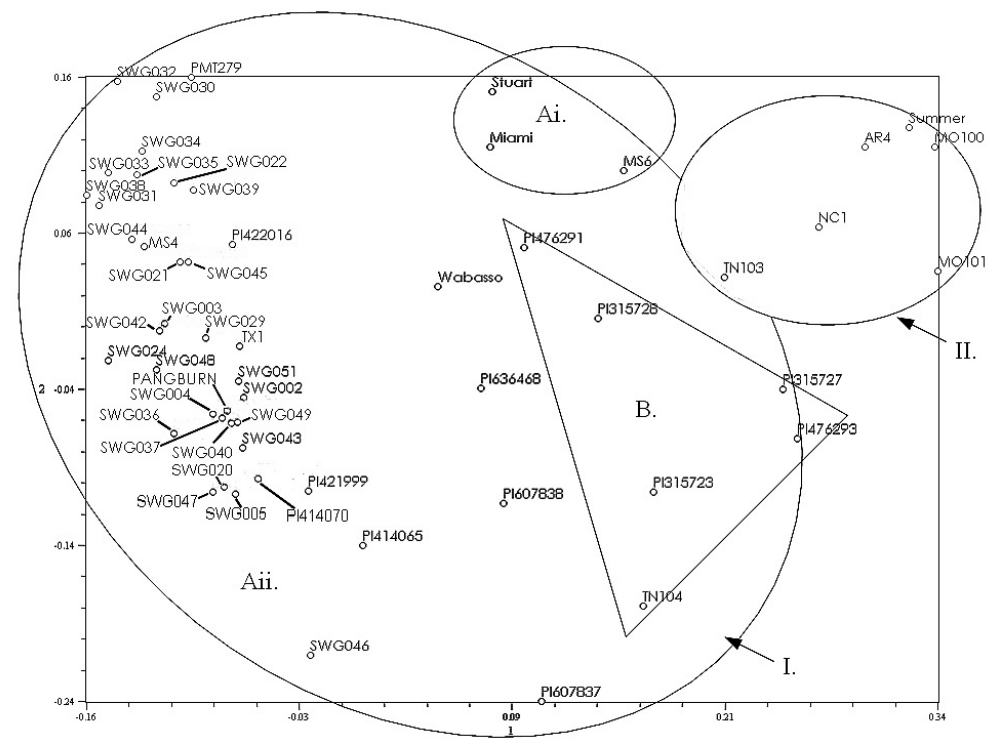

Figure 2. Principle coordinate map based on switchgrass AFLP markers. The numerals and letters were derived from the UPGMA phenogram. Roman numerals I and II represent the major groupings. The letters A and B are subdivisions of I and the lower case Roman numerals $\mathrm{i}$ and ii are subdivisions of A. 
upland tetraploid, segregated with the lowland types. We noted that TN103 and TN104 originated close together geographically but were genetically distinct. The range of diversity in our study was less than in some past studies (for example, Gunter et al. 1996), whose similarity coefficients ranged from 0.53 to 0.78 , and Narasimhamoorthy et al. (2008), whose similarity coefficients ranged from $0.45-0.81$; however, it was much lower than in the study by Cortese et al. (2010) (0.03 to 0.24$)$ and Zalapa et al. (2010) (0.02 to 0.16$)$. The lower diversity in our study could be because it is limited to one plant per accession and switchgrass has higher within accession diversity (Narasimhamoorthy et al., 2008). This difference between our study and others would be expected because our primary purpose was to measure the diversity between different accessions and not within accessions. The differences could also be due to distinct germplasm materials; the inclusion of some of the switchgrass germplasm from the National Plant Germplasm System into the working collection of the OSU breeding program would increase genetic diversity. We used 452 polymorphic dominant markers, while 91 were used by Gunter et al. (1996), 63 EST and genomic SSR loci by Narasimhamoorthy et al. (2008) and 16 EST SSR loci by Cortese et al. (2010). Mohammadi and Prasanna (2003) indicated that a high degree of sampling error could be due to rare alleles, which have $5 \%$ or lower frequency; the percentage of polymorphic markers became reliable only when a large number of loci were generated. However, they did not indicate specific marker numbers for this kind of study. In our study $>400$ polymorphic markers were used to allow a good estimate of genetic diversity.

The Shannon's information index $(I), H_{\mathrm{E}}$ (gene diversity) and $U H_{\mathrm{E}}$, and their respective standard errors, can be found in Table 3 . The $H_{\mathrm{E}}$, percent polymorphic bands and $I$ were higher in the lowland genotypes compared to the upland genotypes. This is not surprising because of the larger number of lowland samples; but it indicates that the germplasm that we investigated is diverse. The addition or subtraction of TN104 only slightly affected $H_{\mathrm{E}}$ and $I$, but it affected percent polymorphic bands more particularly in the upland germplasms. The total $I$ was higher but similar to that found in populations of big bluestem in Ohio, where it ranged from 0.22 to 0.27 based on RAPDs (Selbo and Snow, 2005). The total $I$ and $H_{\mathrm{E}}$ were much higher in switchgrass $\left(I=0.317, H_{\mathrm{E}}=0.208\right)$ than in an AFLP study in Carpetgrass $\left(I=0.24, H_{\mathrm{E}}=0.16\right)$ from samples collected in the United States (Wang et al., 2010).

\begin{tabular}{|c|c|c|c|c|c|c|c|c|c|c|}
\hline & \multicolumn{2}{|c|}{ Upland } & \multicolumn{2}{|c|}{ Upland - TN104 } & \multicolumn{2}{|c|}{ Lowland } & \multicolumn{2}{|c|}{ Lowland + TN104 } & \multicolumn{2}{|c|}{ Total } \\
\hline & Mean & SE & Mean & SE & Mean & SE & Mean & SE & Mean & SE \\
\hline$N_{\mathrm{E}}$ & 1.25 & 0.014 & 1.221 & 0.013 & 1.327 & 0.014 & 1.33 & 0.014 & 1.347 & 0.014 \\
\hline$I^{E}$ & 0.223 & 0.011 & 0.195 & 0.01 & 0.295 & 0.011 & 0.298 & 0.011 & 0.317 & 0.011 \\
\hline$H_{\mathrm{E}}$ & 0.147 & 0.007 & 0.129 & 0.007 & 0.194 & 0.008 & 0.196 & 0.008 & 0.208 & 0.007 \\
\hline$\stackrel{U}{U} H_{\mathrm{E}}$ & 0.159 & 0.008 & 0.141 & 0.008 & 0.196 & 0.008 & 0.198 & 0.008 & 0.21 & 0.008 \\
\hline PPB (\%) & 45.1 & & 38.0 & & 63.5 & & 64.1 & & 68.7 & \\
\hline
\end{tabular}

$\overline{N_{\mathrm{E}}}=$ No. of effective alleles; $I=$ Shannon's information index; $H_{\mathrm{E}}=$ expected heterozygosity; $U H_{\mathrm{E}}=$ unbiased expected heterozygosity; PPB = percentage of polymorphic loci.

\section{AMOVA}

The results of AMOVA were similar with TN104 included in either the upland or lowland ecotypes. There was more diversity within ecotypes than among them in both analyses, 
but the analysis with TN104 (21\% among, 79\% within) as a lowland ecotype had a higher among ecotype variation than the analysis with TN104 (18\% among, $82 \%$ within) as an upland ecotype and a higher PhiPT score (0.18 and 0.21 , respectively). AMOVA PhiPT P value (0.01) was significant with and without TN104 and was significantly different between upland and lowland at $95 \%$ but not at the $99 \%$ significance level. AMOVA revealed that the amount of diversity within ecotypes was high (79\%) and among ecotypes it was low (21\%). High within ecotype diversity allows for breeding and selection within each ecotype.

\section{TrnL marker}

The $\operatorname{trn} \mathrm{L}$ PCR for the entire germplasm was performed and the gel analysis showed lowland germplasm including TN104 ( $\sim 560.5 \mathrm{bp})$ and AR4 ( 563.5 bp) migrated with the shorter lowland DNA of PI 421999 ( $\sim 564.3 \mathrm{bp})$. Moreover, the upland accessions, including lowland accession Miami ( 620 bp), migrated with the longer DNA of Summer ( 612.5 bp) (Figure 3). Once sequenced, it was found that TN104 and AR4 lacked the 49-nucleotide segment that Summer and Miami possess (Figure 4). Miami and AR4 trnL sequences were opposite of what was expected from the AFLP. Miami, which was considered to be a lowland germplasm, had the 49 nucleotide and AR4 lacked this segment, like the lowland germplasms. The Miami results are similar to those found by Gunter et al. (1996), where the cpDNA type of Miami was of the upland type and the RAPD results were lowland. The trnL marker sequenced by Missaoui et al. (2006) from Panicum amarum, to which Miami was phenotypically similar, when aligned also has the 49-nucleotide $\operatorname{tr} n \mathrm{~L}$ sequence typical of uplands. Native hybrids of $P$. amarum var. amarulum and $P$. virgatum had been found (Palmer, 1975). It could be that Miami has chloroplast DNA from P. amarum from a past interspecific cross. AR4 having the lowland marker was unexpected because it clustered with the uplands, which could be caused by gene flow between uplands and lowlands. The $\operatorname{trn} \mathrm{L}$ marker was in the chloroplasts, so if there is hybridization between upland and lowland genotypes, it will measure the contribution of the maternal parent (Martinez-Reyna et al., 2001). Chloroplast capture, the transfer of chloroplasts from one population to another, had been documented in other studies and was found to be possible at the intraspecific level (Wolfe and Elisens, 1995). The trn L analysis confirmed the AFLP analysis that TN104 is a lowland cultivar, but the presence of the lowland trnL marker in AR4 and the upland marker in Miami, when the AFLP clearly indicated otherwise, shows that the marker may not always correlate with upland and lowland genotype or phenotype. Zalapa et al. (2010) found similar results when screening switchgrass cultivars with chloroplast markers. This marker probably is associated with ecotype, but gene flow may occur when upland and lowland ecotypes hybridize in hybrid zones (Modliszewski et al., 2006). The incongruence between the phenotypic markers, AFLP markers and the $\operatorname{trn} \mathrm{L}$ marker indicated the possibility of gene flow between upland and lowland genotypes in some germplasms.

\section{CONCLUSIONS}

The germplasms mostly clustered according to ecotype and then broad geographic regions, but some plants did not. This indicated the possibility of variability within a small area. There was a significant difference between upland and lowland germplasm when analyzed by AFLP. When the data were analyzed by AMOVA and partitioned by upland and lowland 


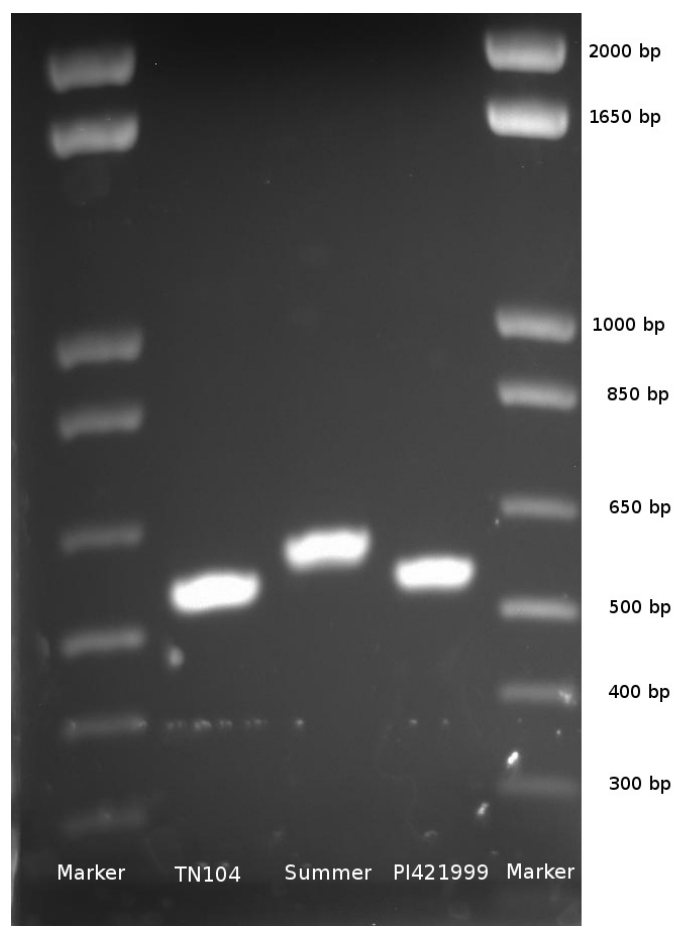

Figure 3. Example of $1 \%$ agarose gel analysis of PCR-amplified switchgrass $\operatorname{trn} \mathrm{L}$ (UAA) intron. Lowland germplasm DNA migrated farther than upland. The controls were Summer (upland) and PI421999 (lowland). TN104 showed a lowland band while it is considered to be an upland germplasm on the basis of morphology.

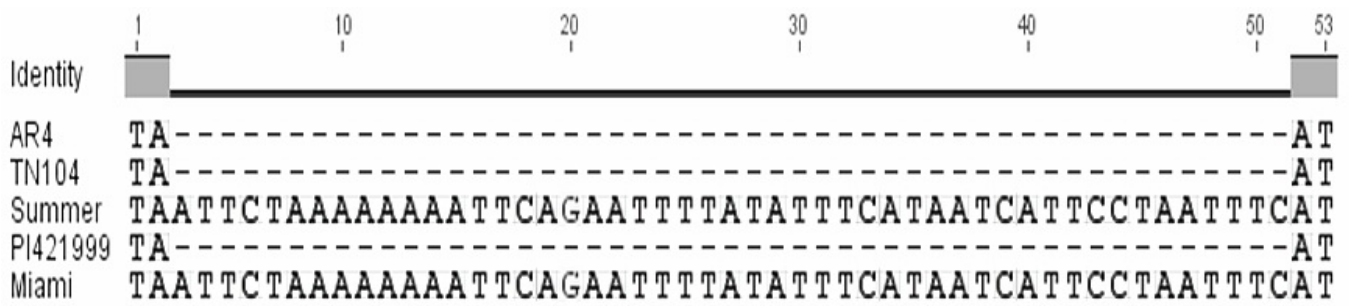

Figure 4. Segment of aligned $\operatorname{trn} \mathrm{L}$ switchgrass sequences showing the 49-nucleotide deletion in lowland genotypes visualized using MEGA (v. 4). 'Summer' (upland) and PI421999 (lowland) are controls. AR4 and TN104 germplasm were considered to be upland but lack the 49-nucleotide segment and Miami was considered to be lowland and contains the segment.

ecotype, the variation within ecotypes was higher than among ecotypes. Upland and lowland germplasm segregated as expected according to phenotypic markers, with exceptions. The polymorphism in the trnL marker was mostly consistent with AFLP and morphology differences to distinguish between upland and lowland germplasm, with the exception of the inconsistency between the $\operatorname{trn} \mathrm{L}$ and the previous morphological phenotyping in germplasm AR4, Miami and TN104. 


\section{ACKNOWLEDGMENTS}

We thank Gary and Sharon Williams and all the field staff for their help in plant maintenance. We also acknowledge the NSF EPSCoR (award EPS \#0814361) and the SunGrant Initiative of the South Central Region for funding the project.

\section{REFERENCES}

Brown AHD and Weir BS (1983). Measuring Genetic Variability in Plant Populations. In: Isozymes in Plant Genetics and Breeding (Tanskley SD and Orton TJ, eds.). Part A. Elsevier, Amsterdam, 219-229.

Brummer EC (1999). Capturing heterosis in forage crop cultivar development. Crop Sci. 39: 943-954.

Casler MD, Stendal CA, Kapich L and Vogel KP (2007). Genetic diversity, plant adaptation regions, and gene pools for switchgrass. Crop Sci. 47: 2261-2273.

Cortese LM, Honig J, Miller C and Bonos SA (2010). Genetic diversity of twelve switchgrass populations using molecular and morphological markers. Bioenerg. Res. 3: 262-271.

Gunter LE, Tuskan GA and Wullschleger SD (1996). Diversity among populations of switchgrass based on RAPD markers. Crop Sci. 36: 1017-1022.

Hartl DL and Clark AG (1997). Principles of Population Genetics. Sinauer, Sunderland.

Hitchcock AS (1935). Manual of the Grasses of the United States. USDA Miscellaneous, U.S. Government Printing Office, Washington.

Hopkins AA, Taliaferro CM, Murphy CD and Christian D (1996). Chromosome number and nuclear DNA content of several switchgrass populations. Crop Sci. 36: 1192-1195.

Kumar S, Nei M, Dudley J and Tamura K (2008). MEGA: a biologist-centric software for evolutionary analysis of DNA and protein sequences. Brief. Bioinform. 9: 299-306.

Lynch M and Milligan BG (1994). Analysis of population genetic structure with RAPD markers. Mol. Ecol. 3: 91-99.

Martinez-Reyna JM and Vogel KP (2008). Heterosis in switchgrass spaced plants. Crop Sci. 48: 1312-1320.

Martinez-Reyna JM, Vogel KP, Caha C and Lee DJ (2001). Meiotic stability, chloroplast DNA polymorphisms, and morphological traits of upland x lowland switchgrass reciprocal hybrids. Crop Sci. 41: 1579-1583.

McLaughlin SB and Kszos LA (2005). Development of switchgrass (Panicum virgatum) as a bioenergy feedstock in the United States. Biomass Bioenerg. 28: 515-535.

McLaughlin SB, Bouton J, Bransby D, Conger B, et al. (1999). Progress in Developing Switchgrass as a Bioenergy Feedstock. In: Perspectives on New Crops and New Uses (Janick J, ed.). ASHS Press, Alexandria, 282-298.

Meudt HM and Clarke AC (2006). Almost forgotten or latest practice? AFLP applications, analyses and advances. Trends Plant Sci. 12: 1360-1385.

Missaoui AM, Paterson AH and Bouton JH (2006). Molecular markers for the classification of switchgrass (Panicum virgatum L.) germplasm and to assess genetic diversity in three synthetic switchgrass populations. Genet. Res. Crop Evol. 53: 1291-1302.

Modliszewski JL, Thomas DT, Fan C, Crawford DJ, et al. (2006). Ancestral chloroplast polymorphism and historical secondary contact in a broad hybrid zone of Aesculus (Sapindaceae). Am. J. Bot. 93: 377-388.

Mohammadi SA and Prasanna BM (2003). Analysis of genetic diversity in crop plants-salient statistical tools and considerations. Crop Sci. 43: 1235-1248.

Narasimhamoorthy B, Saha M, Swaller T and Bouton J (2008). Genetic diversity in switchgrass collections assessed by EST-SSR markers. Bioenerg. Res. 1: 136-146.

Palmer PG (1975). A biosystematic study of the Panicum amarum-P. amarulum complex (Gramineae). Brittonia 27: 142-150.

Peakall R and Smouse PE (2006). GENALEX 6: genetic analysis in Excel. Population genetic software for teaching and research. Mol. Ecol. Notes 6: 288-295.

Pirie MD, Vargas MPB, Botermans M, Bakker FT, et al. (2007). Ancient paralogy in the cpDNA trnL-F region in Annonaceae: implications for plant molecular systematics. Am. J. Bot. 94: 1003-1016.

Rohlf FJ (1993). NTSYS-pc. Numerical Taxonomical and Multivariate Analysis System. Exeter Software, Setauket, New York.

Selbo SM and Snow AA (2005). Flowering phenology and genetic similarity among local and recently introduced populations of Andropogon gerardii in Ohio. Restor. Ecol. 13: 441-447.

Singh A, Negi MS, Rajagopal J, Bhatia S, et al. (1999). Assessment of genetic diversity in Azadirachta indica using AFLP 
markers. Theor. Appl. Genet. 99: 272-279.

Taberlet P, Gielly L, Pautou G and Bouvet J (1991). Universal primers for amplification of three non-coding regions of chloroplast DNA. Plant Mol. Biol. 17: 1105-1109.

Vogel KP (2004). Switchgrass. In: Warm-season (C4) grasses (Moser LE, Sollenberger L and Burson B, eds.). Agronomy Monograph, Madison, 561-588.

Vos P, Hogers R, Bleeker M, Reijans M, et al. (1995). AFLP: a new technique for DNA fingerprinting. Nucleic Acids Res. 23: 4407-4414.

Waller SS and Lewis JK (1979). Occurrence of $\mathrm{C}_{3}$ and $\mathrm{C}_{4}$ photosynthetic pathways of North American grasses. J. Range Manage. 32: 12-28.

Wang Z, Kenworthy KE and Wu Y (2010). Genetic diversity of common carpetgrass revealed by amplified fragment length polymorphism markers. Crop Sci. 50: 1366-1374.

Wolfe AD and Elisens WJ (1995). Evidence of chloroplast capture and pollen-mediated gene flow in Penstemon sect. Peltanthera (Scrophulariaceae). Syst. Bot. 20: 395-412.

Wu YQ, Taliaferro CM, Bai GH and Anderson MP (2005). Genetic diversity of Cynodon transvaalensis Burtt-Davy and its relatedness to hexaploid C. dactylon (L.) Pers. as indicated by AFLP markers. Crop Sci. 45: 848-853.

Zalapa JE, Price DL, Kaeppler SM, Tobias CM, et al. (2010). Hierarchical classification of switchgrass genotypes using SSR and chloroplast sequences: ecotypes, ploidies, gene pools, and cultivars. Theor. Appl. Genet. 122: 805-817. 